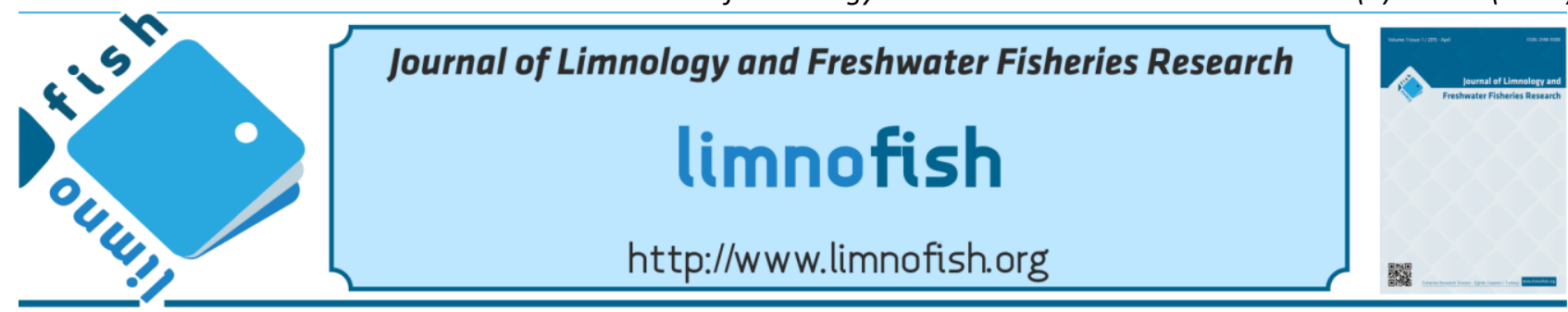

\title{
The Aquatic Oligochaeta (Annelida) Fauna of the Karasu Stream
}

\author{
Melek ZEYBEK ${ }^{1 *}$ (D) Serap KOŞAL ŞAHIN ${ }^{2}$ (iD) Seray YILDIZ ${ }^{3}$ (D) \\ ${ }^{1}$ Süleyman Demirel University, Faculty of Arts and Sciences Department of Biology, 32260, Isparta, Turkey \\ ${ }^{2}$ Istanbul University, Faculty of Fisheries, 34134, Laleli, İstanbul, Turkey \\ ${ }^{3}$ Ege University, Faculty of Fisheries, Department of Hydrobiology, 35100, Bornova, İzmir, Turkey
}

\section{A B STRACT}

Sakarya River is defined hydrologically in three parts: upper, middle and lower Sakarya River Basin. This study was carried out in lower Sakarya River (Karasu). Aquatic Oligochaeta samples were collected from four chosen stations between January 2008 and October 2008 seasonally. In total, eight Oligochaeta species were identified during the study period. These species belong to Naididae family and to Tubificinae subfamily (Tubificoid Naidid) [Limnodrilus hoffmeisteri Claparède, 1862; Limnodrilus udekemianus Claparède, 1862; Limnodrilus claparedeianus Ratzel, 1868; Potamothrix hammoniensis (Michaelsen, 1901); Psammoryctides deserticola (Grimm, 1877); Tubifex blanchardi Vejdovsky, 1891; Tubifex ignotus (Stolc, 1886); Tubifex tubifex (Müller, 1774)]. Also, it was observed that Limnodrilus hoffmeisteri and Tubifex tubifex, were found to be dominant, and thus indicator species for pollution in the river.

Keywords: Oligochaeta, Karasu, Sakarya River

\section{ARTICLE INFO}

\section{RESEARCH ARTICLE}

Received : :08.12.2017

Revised : 20.03.2018

Accepted : 30.03 .2018

Published : 27.04.2018

DOI:10.17216/LimnoFish.363933

\section{* CORRESPONDING AUTHOR}

melekzeybek@sdu.edu.tr

Tel : +90 2462114075

\section{Karasu Nehri'nin Sucul Oligochaeta (Annelida) Faunası}

Öz: Sakarya Nehir havzası; yukarı, orta ve aşağı (Karasu) olmak üzere üç bölüme ayrılır. Bu çalışma Aşağı Sakarya (Karasu) Nehri'nde gerçekleștirilmiștir. Akarsu üzerinde dört istasyon seçilmiş ve bu istasyonlardan Ocak 2008-Ekim 2008 tarihleri arasında mevsimsel periyotlarla Oligochaeta örnekleri toplanmıştır. Çalışma sonunda, Oligochaeta sınıfına ait sekiz tür bulunmuştur. Bu türler Naididae familyasından ve Tubificinae (Tubificoid Naidid) alt familyasındadır [Limnodrilus hoffmeisteri Claparède, 1862; Limnodrilus udekemianus Claparède, 1862; Limnodrilus claparedeianus Ratzel, 1868; Potamothrix hammoniensis (Michaelsen, 1901); Psammoryctides deserticola (Grimm, 1877); Tubifex blanchardi Vejdovsky, 1891; Tubifex ignotus (Stolc, 1886); Tubifex tubifex (Müller, 1774)]. Ayrıca çalışmada, kirlilik indikatörü olarak bilinen Limnodrilus hoffmeisteri ve Tubifex tubifex türlerinin nehirde baskın olduğu gözlenmiştir.

Anahtar kelimeler: Oligochaeta, Karasu, Sakarya Nehri

How To Cite

Zeybek M, Koşal Şahin S, Yıldız S. 2018. The Aquatic Oligochaeta (Annelida) Fauna of the Karasu Stream. LimnoFish. 4(1): 30-35. doi: 10.17216/LimnoFish.363933

\section{Introduction}

Sakarya River is the third largest river in Turkey pouring into the Black Sea. Sakarya River basin, which is the most important river in the region, is an important source of natural energy. With the dams built on the area it provides drinking and irrigation water. The length of this river is approximately $810 \mathrm{~km}$ and its width $60-150 \mathrm{~m}$. The river is divided into three sections in terms of hydrology: upper, middle and lower Sakarya (Karasu) River Basin (DSI 1992; Anonymous 2015). This river is used for purposes such as usage water, recreation, agricultural irrigation, and wastewater discharge of residential and industrial establishments. There have been many water pollution problems, due to increase in population and industrialization, and it was determined that some branches of river were significantly contaminated by waste discharges of industrial plants (Dündar 2008; Balc1oğlu and Öztürk 2009). Moreover, the oil pollution level was found higher than the limit value given by UNESCO in Sakarya River (Balcıoğlu and Öztürk 2009). 
There are various studies to determine the Oligochaeta fauna in both the lotic and lentic areas of the Sakarya River Basin (Arslan and Şahin 2003, 2004; Arslan et al. 2007; Y1ld1z et al. 2008). The number of studies is very limited in Karasu Stream on this subject (Arslan and Şahin 2004).

Karasu Stream, which is chosen as a research area in this study, is one of the water sources of the lower Sakarya basin. However, this stream has not been thoroughly investigated in terms of Oligochaeta fauna except a few studies in lentic habitats (Y1ldiz et al. 2008). Therefore, in this study, it was aimed to determine the Oligochaeta fauna of Karasu River.

\section{Material and Methods}

This study was carried out on Karasu River located in the lower part of Sakarya River basin (Turkey). This river is originated from Çataltepe near Hendek. It first flows to north with the name Kabalak Stream. After it merges with Yayla Stream, it takes the name of Karasu and it is poured from Karasu district to the Black Sea. The length of study area is approximately $30 \mathrm{~km}$. Four stations were chosen on this river and samples were taken seasonally between January 2008 - October 2008 (Figure 1). Totally, 16 samples had been performed per site/single sampling from four stations at four seasons.

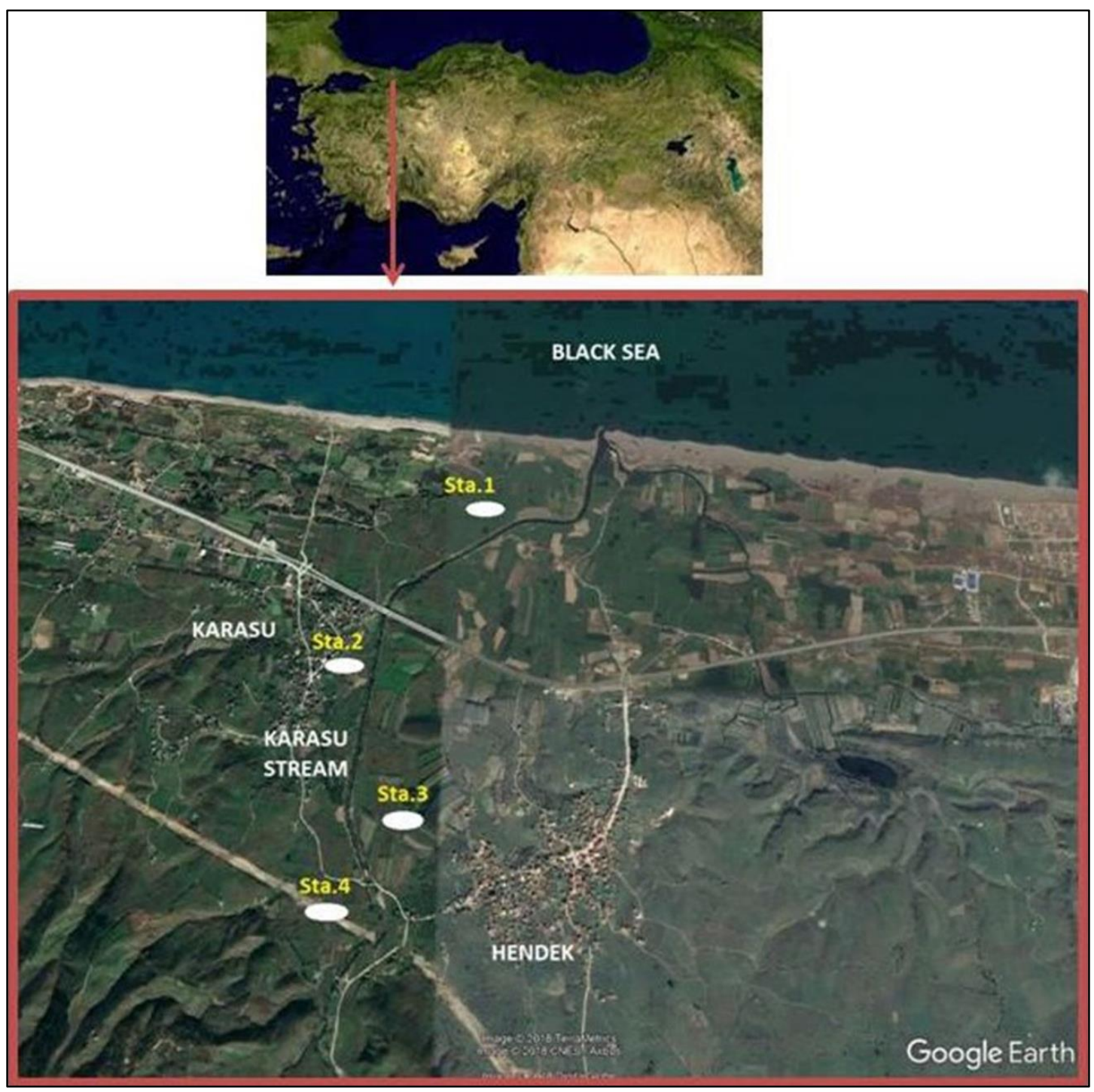

Figure 1. The study area and stations

Oligochaeta specimens were collected twice from each station by using Ekman-Birge grab $(15 \times 15 \mathrm{~cm})$ and a hand-net with a mesh size (with sweeping method) $180 \mu \mathrm{m}$. Then, they were sieved through a mesh of $500 \mu \mathrm{m}$. The samples were preserved in the field with $4 \%$ formaldehyde solution and preserved in $70 \%$ alcohol until identification after washing in the laboratory. After the permanent preparation of sorted Oligochaeta specimens with CMCP-10 
(polyvinyl lactophenol), samples were identified in species level under stereomicroscope and binocular microscopes. Samples were identified according to Brinkhurst and Jamieson (1971), Kathmanand Brinkhurst (1998), Timm (1999),
Timm and Veldhuijzenvan Zanten (2002). ShannonWeaver (1963) and Simpson (1949) indices were applied to detect the species diversity of the stations by using MVSP version 3.1 (Kovach 1998).

Table 1. The Secchi depth values (meter) of the stations.

\begin{tabular}{cccccc}
\hline & & Station 1 & Station 2 & Station 3 & Station 4 \\
\hline \multirow{2}{*}{ Secchi } & Winter'08 & 2.3 & 2.5 & 4 & 3.2 \\
Depth & Spring'08 & 2.3 & 1.3 & 4 & 4 \\
(m) & Summer'08 & 2.3 & 1.5 & 3.8 & 4 \\
& Autumn'08 & 2.3 & 2.5 & 4 & 3.2 \\
\hline
\end{tabular}

\section{Results}

In total, eight taxa were determined from Naididae family and Tubificinae subfamily (Tubificoid Naidid) at the end of the study.

The list and density of Oligochaeta species at the stations were shown in Table 2. Limnodrilus hoffmeisteri was the only taxon seen in all seasons and L. hoffmeisteri and Tubifex tubifex were found at the all stations. The species diversity values ranged from 1.27 to 1.5 for Shannon Weaver index and between 0.43-0.6 for Simpson index. In addition, evenness value of the second station was calculated rather low compared to the other stations. Additionally, the lowest diversity value was observed in the autumn and there was only one taxon (Table 2).

Table 2. Seasonal distribution and the density values of the determined taxa.

\begin{tabular}{|c|c|c|c|c|c|}
\hline & & Sta 1. & Sta 2. & Sta 3. & Sta.4 \\
\hline & OLIGOCHAETA & & & & \\
\hline & Naididae & & & & \\
\hline & Tubificinae & & & & \\
\hline \multirow{6}{*}{ Winter'08 } & Limnodrilus hoffmeisteri Claparède, 1862 & 889 & 4444 & 1778 & 222 \\
\hline & Limnodrilus claparedeianus Ratzel, 1868 & & 222 & & \\
\hline & Limnodrilus udekemianus Claparède, 1862 & & 222 & 2444 & \\
\hline & Tubifex ignotus(Stolc, 1886) & & 1110 & & \\
\hline & Tubifex tubifex (Müller, 1774) & 444 & & 2889 & 889 \\
\hline & Tubifex blanchardi Vejdovsky, 1891 & & & & 444 \\
\hline \multirow{3}{*}{ Spring'08 } & Limnodrilus hoffmeisteri Claparède, 1862 & & & 1110 & \\
\hline & Potamothrix hammoniensis (Michaelsen, 1901) & & & 222 & \\
\hline & Tubifex tubifex (Müller, 1774) & & & 2223 & \\
\hline \multirow{4}{*}{ Summer'08 } & Limnodrilus hoffmeisteri Claparède, 1862 & & 2000 & & \\
\hline & Tubifex tubifex (Müller, 1774) & 889 & 444 & & \\
\hline & Tubifex blanchardi Vejdovsky, 1891 & 222 & & & \\
\hline & Psammoryctides deserticola (Grimm, 1877) & 222 & & & \\
\hline \multirow[t]{5}{*}{ Autumn'08 } & Limnodrilus hoffmeisteri Claparède, 1862 & & 444 & & \\
\hline & Species Diversity Indices & & & & \\
\hline & Shannon-Weaver & 1.424 & 1.268 & 1.502 & 1.378 \\
\hline & Simpson & 0.539 & 0.431 & 0.59 & 0.571 \\
\hline & Evenness & 0.719 & 0.538 & 0.786 & 0.857 \\
\hline
\end{tabular}


The total densities of Oligochaets in each station showed considerable differences during the study period; the highest total density of specimens (7111 ind $\mathrm{m}^{-2}$ ) was recorded at the station 3 in winter period. Oligochaeta species were detected at the third station in the spring while at the second station in the autumn (Fig 2). Most of the determined species, especially the Tubificid ones, are characteristic for eutrophic lakes. In particular, $T$. tubifex and L. hoffmeisteri together with Potamothrix hammoniensis have high densities throughout the river. Table 2 clearly shows the eutrophic structure of the river. Also, low Shannon-Weaver values are due to the influence of pollution according to Orclari and Hummon (1975) from high relative intensities of some species according to Statzner 1981; Sang, 1987. In our study, the presence of L. hoffmeisteri as the only and dominant species in the second station reduced the value of the diversity index. This information supports the study results.

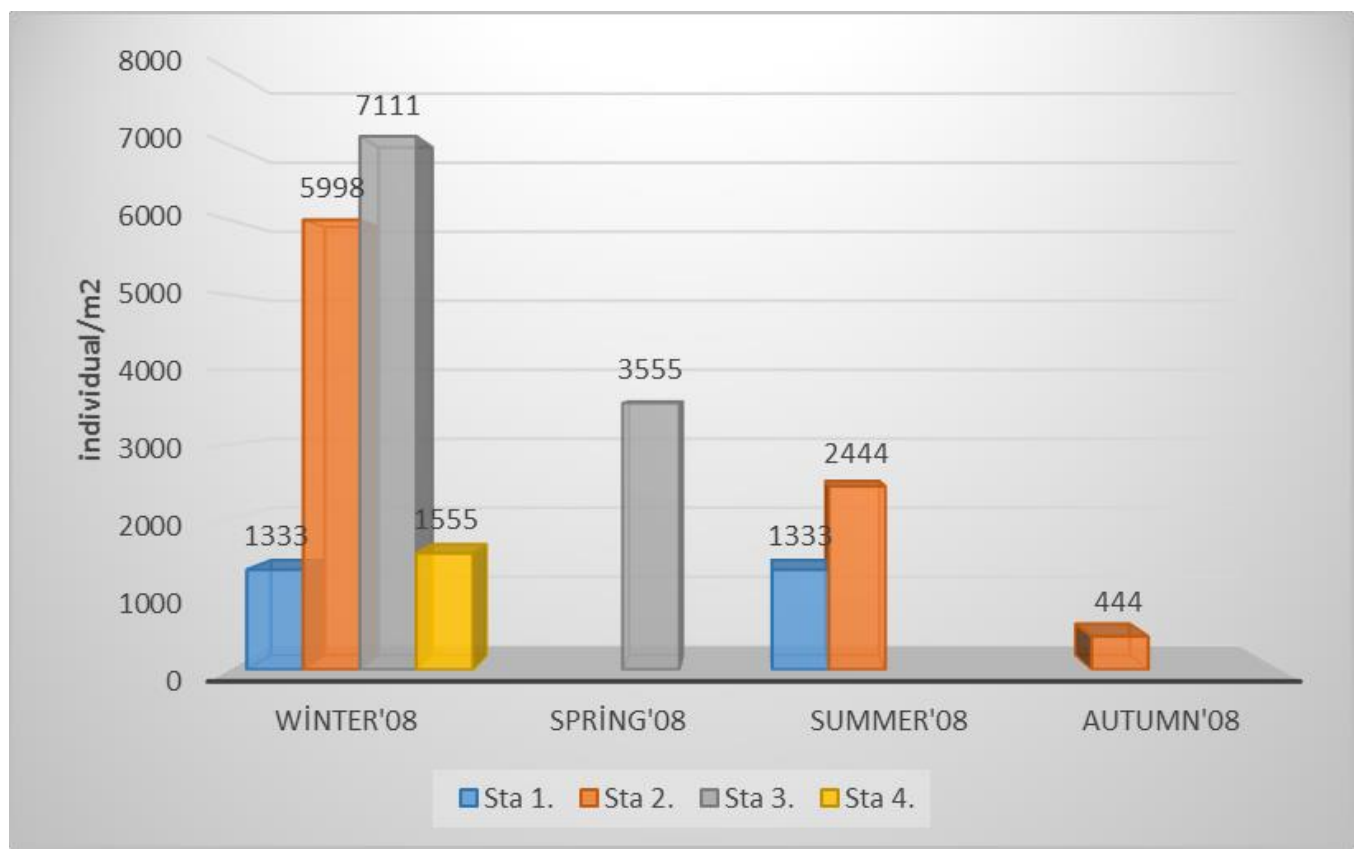

Figure 2. Seasonal abundances of the total Oligochaeta population at the stations during the study.

\section{Discussion}

This study was carried out on the Karasu Stream, one of the important branches of the Sakarya River and eight taxa were determined belong to Naididae family and Tubificinae subfamily. Naididae is one of the most important groups of aquatic Oligochaeta and they are cosmopolitan and occur throughout the world (Martin et al. 2008). Especially, taxa in subfamily Tubificinae (Tubificoid Naidid newly) are commonly associated with sediments in aquatic habitats (Y1ldiz et al. 2012).

Arslan and Şahin (2003) collected Oligochaeta samples from 79 stations on the Sakarya River. Five taxa were determined on Karasu Stream in their work. There are some differences in terms of species composition between those reported by Arslan and Şahin (2003) and the present study. Ophidonais serpentina, Nais pardalis, Pristinella jenkinae, Pristina aequiseta, and Pristina foreli were reported from the Karasu Stream. Also, several studies have been carried out to determine the Oligochaeta fauna in several branches of the Sakarya River and lentic areas of this river basin (Arslan and Şahin 2003, 2004; Arslan et al. 2007; Y1ldiz et al. 2008). In this study, L. hoffmeisteri and T. tubifex were found at the all stations.

L. hoffmeisteri is a very common, pollutiontolerant species in freshwaters and it is found in large numbers in densely polluted waters (Brinkhurst and Jamieson 1971; Mason 1996). It happens densely populated in polluted habitats, often together with T. tubifex.

T. tubifex is a cosmopolitan species and it is tolerant against organic pollution and lack of oxygen (Klemm 1985; Timm 1999; Y1ld1z and Balık 2005). According to Milbrink (1983), this species occurs in those environments where competition or predation is weak.

L. hoffmeisteri and T. tubifex have poly-sabrobic character (Johnson et al. 1993). These species are the typical species of heavily polluted waters in several indices running on benthic macroinvertebrates (Armitage et al. 1983).

L. udekemianus is a cosmopolitan species and is mostly found in organically polluted waters as well 
as oligotrophic habitats (Klemm 1985). This species was found in winter at the second and third stations in this study. This species is often found together with $L$. hoffmeisteri but less in number (Timm 1970).

P. hammoniensis, is a reliable an indicator for eutrophy and it has a wide distribution pattern and can be found in brackish waters occasionally (Milbrink 1980; Lang 1984). In addition, it is known to be extremely tolerant to anoxic conditions in brackish or moderately alkaline bottom water (Milbrink 1980). This species was found only at the third station and had a low dominance in this study. Milbrink (1973) found this species generally associated with pollution and most often together with T. ignotus (Stolc 1886), which has Palaearctic distribution in Swedish waters after (Milbrink 1980), is found great rivers and deep lakes.

$T$. blanchardi is a freshwater tubificid, often occurring together with T. tubifex (Marotta et al. 2009). It has a large tolerance range and can live in various habitats (Y1ldiz 2003). In certain conditions, $\mathrm{pH}$, salinity, mercury and hardness concentrations make stress on T. tubifex specimens and induce a gradial loss of hair and pectinate setae thus generating individuals similar to "blanchi" form (Marotta et al. 2009).

L. claparedeianus Ratzel, 1868, which is freshwater species with tolerance for slightly brackish water, and Psammoryctides deserticola (Grimm 1877), which is common, euryhalin and Ponto-Caspian immigrant specieshave the least dominance value in that study. L. claparedeianus and $P$. deserticola were observed only at stations 2 and 3 , respectively.

Findings from this preliminary study on the taxonomic determination of the Karasu Stream Oligochaeta fauna suggest that the species forming the river fauna are generally cosmopolitan, or at least species with broad distribution in the Palearctic region (Timm, 1980). The results show that the river does not have a high diversity in terms of the Oligochaeta fauna.

Although there is no measurement of water quality and pollutants in the study, in the molluscan study conducted in the same region; according to the results of the seasonal measurements of nitrite, nitrate nitrogen, water temperature and $\mathrm{pH}$ measurements of the Lower Sakarya River where the survey was conducted according to the Water Quality and Control Regulation (SKKY) (2004), it falls into the category 3 (contaminated water) (Koşal-Şahin 2013). The pollution indicators Oligochaets like L. hoffmeisteri and T. tubifex were observed in high numbers and have a great dominancy especially at stations 2 and 3 where pollution level was high.

\section{References}

Anonymous 2015. The environmental situation report of Sakarya city. Sakarya: Sakarya Governor Environmental and Citizenship Province Directorate 116 p. [in Turkish]

Armitage PD, Moss D, Wright JF, Furse MT. 1983. The performance of a new biological water quality score system based on macroinvertebrates over a wide range of unpolluted running-water sites. Water Res. 17(3): 333-347. doi: 10.1016/0043-1354(83)90188-4

Arslan N, Şahin Y. 2003. Nine New Naididae (Oligochaeta) Species for Sakarya River, Turkey. Turk J Zool. 27(1): 27-38.

Arslan N, Şahin Y. 2004. First records of some Oligochaeta (Naididae) species for Turkey and Sakarya River Fauna. Turk J Zool. 28(1): 7-18.

Arslan N, Timm T, Erséus C. 2007. Aquatic Oligochaeta (Annelida) of Balıkdamı wetland (Turkey), with description of two new species of Phallodrilinae. Biologia. 62(3): 323-334. doi: 10.2478/s11756-007-0055-y

Balcıŏlu EB, Öztürk B. 2009. Oil pollution in the surface water of Sakarya River. J. Black Sea/Mediterranean Environment. 15(2): 99-108.

Brinkhurst RO, Jamieson BGM. 1971. Aquatic Oligochaeta of the World. Edinburgh: Oliver\& Boyd $860 \mathrm{p}$.

DSI (General Directorate of the State Water) 1992 General directorate of the state water, Investigation of pollution aspects of Sakarya-Seyhan Basins and report of determination of quality classes of these basins, 5, Ankara. [in Turkish]

Dündar MŞ. 2008. Aşağı Sakarya Nehri Su ve Sediment Kalitesinin Belirlenmesi. Türkiye Bilimsel ve Teknolojik Araştırma Kurumu. Proje No: 106Y037. [in Turkish]

Johnson RK, Wiederholm T, Rosenberg DM. 1993. Freshwater biomonitoring using individual organisms, populations, and species assemblages of benthic macroinvertebrates. In: Rosenberg DM, Resh VH. (Eds.), Freshwater Biomonitoring and Benthic Macroinvertebrates. New York : Chapman and Hall p. $40-158$.

Kathman RD, Brinkhurst RO. 1998. Guide to the Freshwater Oligochaetes of North America. Tennessee, USA: Aquatic Resources Center, College Grove 264 p.

Klemm DJ. 1985. A Guide to the Freshwater Annelida (Polychaeta, Naidid and Tubificid Oligochaeta, and Hirudinea) of North America. Dubuque, Iowa: Kendall/Hunt Publishing Company 198 p.

Koşal Şahin S. 2013. Mollusca Species of Down Sakarya River (Karasu) and Some Physico-Chemical Variables Effecting Their Abundance. Yunus Research Bulletin 2013 (3): 11-19.

doi: 10.17693/yunusae.v2013i21904.235413 
Kovach W. 1998. Multi-Variate statistical package. Ver. 3.0. Pentraeth, Wales: Kovach Computer Services.

Lang C. 1984. Eutrophication of Lakes Léman and Neuchâtel (Switzerland) indicated by oligochaete communities. In: Bonomi G, Erséus $\mathrm{C}$, editors. Aquatic Oligochaeta. Developments in Hydrobiology. Dordrecht : Springer. p. 131-138.

doi: 10.1007/978-94-009-6563-8_23

Marotta R, Crottini A, Prada V, Ferraguti M. 2009. A morphological reappraisal of Tubifex blanchardi Vejdovský, 1891 (Clitellata: Tubificidae). Acta Zool. 90 (2): 179-188. doi: 10.1111/j.1463-6395.2008.00368.x

Martin P, Martínez-Ansemil E, Pinder A, Timm T, Wetzel MJ. 2008. Global diversity of oligochaetous clitellates (Oligochaeta; Clitellata) in freshwater. Hydrobiologia 595 (1): 117-127. doi: 10.1007/s10750-007-9009-1

Mason CF. 1996. Organic pollution. In: Mason C, editor. Biology of Freshwater Pollution, 3rd ed. Essex: Longman Scientific \& Technical. p. 82-88.

Milbrink G. 1973. On the use of indicator communities of Tubificidae and some Lumbriculidae in the assessment of water pollution in Swedish lakes. Zoon 1(2): 125-139.

Milbrink G. 1980. Oligochaeta Communities in Pollution Biology: The European Situation with Special Reference to Lakes in Scandinavia. In: Brinkhurst RO, Cook DG, editors. Aquatic Oligochaeta Biology. New York: Plenum Press. p. 433-455.

Milbrink G. 1983. An improved environmental index based on the relative abundance of oligochaete species. Hydrobiologia 102(2): 89-97.

Orclari, RD., Hummon WD. 1975. A comparison of benthic oligochaete populations in acid and neutral lentic environments in Southeastern Ohio. Ohio J. Sci. 75 (1): 46-49.

Sang Q. 1987. Some ecological aspects of aquatic oligochaetes in the Lower Pearl River (People's Republic of China). Hydrobiologia 155 (1): 199-208. doi:10.1007/978-94-009-3091-9_27

Shannon CE, Wiener W. 1963. The mathematical theory of Communication University. Urbana: Illinois Press. $125 \mathrm{p}$.
SKKY. 2004. Su Kirliliği Kontrol Yönetmeliği 25687 Sayılı resmi Gazete.

Simpson EH. 1949. Measurement of diversity. Nature. 163,688 .

doi:10.1038/163688a0

Statzner B. 1981. Shannon-Weaver diversity of the macrobenthos in the Schierensee brooks (North Germany) and problems of its use for the interpretation of the community structure. Verh int Verein Limnol. 21(2): 782-786. doi:10.1080/03680770.1980.11897087

Timm T, Veldhuijzen van Zanten HH. 2002. Freshwater Oligochaeta of North-West Europe. World Biodiversity Database, CD-ROM Series. University of Amsterdam: Expert Center for Taxonomic Identification.

Timm T. 1970. On the Fauna of the Estonian Oligochaeta. Pedobiologia. 10 (1):52-78.

Timm T. 1980. Distribution of Aquatic Oligochaetes. In: Brinkhurst RO, Cook DG, editors. Aquatic Oligochaeta Biology. New York: Plenum Press. p. 55-77.

Timm T. 1999. A Guide to the Estonian Annelida. Naturalist's Handbooks 1. Tartu-Tallinn: Estonian Academy Publishers 208 p.

Y1ldız S, Balık S. 2005.The Oligochaeta (Annelida) fauna of the inland waters in the Lake District (Turkey). Ege J Fas. 22 (1-2): 165-172.

Yıldız S, Özbek M, Ustaoğlu MR, Sömek H. 2012. Distribution of aquatic oligochaetes (Annelida, Clitellata) of high-elevation lakes in the Eastern Black Sea Range of Turkey. Turk J Zool. 36(1):59-74.

doi:10.3906/zoo-1002-39

Yıldız S, Ustaoğlu MR, Balık S, Sarı HM. 2008. Contributions to the Knowledge of Oligochaeta (Annelida) Fauna of Some Lakes in the West Black Sea Region. J. Black Sea/Mediterranean Environment. 14 (3):193-204.

Y1ldiz S. 2003. Taxonomical and ecological investigation of inland waters Oligochaeta (Annelida) fauna in the Lakes district [PhD Thesis]. Ege University 216 p. [in Turkish] 